\title{
Action of phosphorylated mannanoligosaccharides on immune and hematological responses and fecal consistency of dogs experimentally infected with enteropathogenic Escherichia coli strains
}

\author{
E.M.M.F. Gouveia ${ }^{1}$, I.S. Silva ${ }^{1}$, G. Nakazato $^{2}$, V.J.V. Onselem ${ }^{3}$, R.A.C. Corrêa ${ }^{3}$, \\ F.R. Araujo ${ }^{4}$, M.R. Chang ${ }^{1}$ \\ ${ }^{1}$ Programa de Pós-Graduação em Saúde e Desenvolvimento para a Região Centro-Oeste, Universidade \\ Federal de Mato Grosso do Sul, Campo Grande, MS, Brazil. \\ ${ }^{2}$ Departamento de Microbiologia, Universidade Estadual de Londrina, Londrina, PR, Brazil. \\ ${ }^{3}$ Departamento de Cirurgia, Universidade Federal de Mato Grosso do Sul, Campo Grande, MS, Brazil. \\ ${ }^{4}$ Embrapa Gado de Corte, Campo Grande, MS, Brazil.
}

Submitted: July 30, 2011; Approved: September 10, 2012.

\begin{abstract}
The therapeutic action of phosphorylated mannanoligosaccharides (MOS) was investigated regarding its prebiotic activity on enteropathogenic Escherichia coli (EPEC). Diarrhea was induced in dogs by experimental infection with EPEC strains. Then MOS was supplied once a day, in water for 20 days. Immunological (IgA and IgG), hematological (lymphocytes, neutrophils and monocytes) and bacteriological variables (PCR detection of the eae gene of EPEC recovered from stool culture), as well as occurrence of diarrhea were evaluated. All strains caused diarrhea at 24, 48 and $72 \mathrm{~h}$ after infection. PCR results indicated that $E$. coli isolated from stool culture of all infected animals had the eae gene. There was no significant difference among groups as to number of blood cells in the hemogram and IgA and IgG production. MOS was effective in recovering of EPEC-infected dogs since prebiotic-treated animals recovered more rapidly from infection than untreated ones $(p<0.05)$. This is an important finding since diarrhea causes intense dehydration and nutrient loss. The use of prebiotics for humans and other animals with diarrhea can be an alternative for the treatment and prophylaxis of EPEC infections.
\end{abstract}

Key words: enteropathogenic E. coli, in vivo experiment, dogs, phosphorylated 31 mannanoligosaccharides, PCR.

\section{Introduction}

Phosphorylated mannanoliglaueosaccharides (MOS) act beneficially since they modulate the immune response of animals by presenting the pathogen to Peyer's patches. Pathogens and toxins associated with MOS form a great blend that is easily identified by the immune system. Studies have reported higher production of serum immunoglobulin A ( $\operatorname{IgA})$ in dogs, in addition to higher neutrophil activity (Laue and Tucker, 2006). Bio-Mos ${ }^{\circledR}$ (AllTech) is a phosphorylated mannanoligosaccharide extracted from the cell walls of the yeast Sacharomyces cerevisae. This complex is rich in mannose and occupies the pathogen binding site, preventing bacteria from binding to mannose receptors in the intestinal epithelium and colonizing the host cells (Collet, 2000).

Escherichia coli is a facultative anaerobic bacterium that inhabits the intestine of humans and animals (Drasar and Hill, 1974). The following diarrheagenic E. coli variants are currently known to have acquired virulence: Shiga toxin-producing E. coli (STEC), enterotoxigenic E. coli (ETEC), enteropathogenic E. coli (EPEC), enteroinvasive E. coli (EIEC), enterohemorrhagic E. coli (EHEC) and enteroaggregative E. coli (EAEC) (Nataro and Kaper, 1998).

Send correspondence to E.M.M.F. Gouveia. Programa de Pós-Graduação em Saúde e Desenvolvimento para a Região Centro-Oeste, Universidade Federal de Mato Grosso do Sul, Avenida das Bandeiras 1296, 79080-001, Campo Grande, MS, Brazil. E-mail: saudeanimalms@terra.com.br. 
The lesions produced by EPEC infections in the intestinal epithelium are named attaching and effacing (A/E) lesions. This phenomenon is characterized by intimate bacterial adherence to the intestinal epithelium. The presence of $\mathrm{A} / \mathrm{E}$ lesions is associated with a disarranging in the enzymatic system of digestive absorption, leading to malabsorption (Nataro and Kaper, 1998) and accumulation of actin and other cytoskeletal proteins, which results in the formation of pedestal-like structures (Cray and Moon, 1995). In the II International Symposium on EPEC, in 1995, researchers classified EPEC samples into two categories (Kaper, 1996): typical EPECs, which cause A/E lesions and have the eae gene and the EAF plasmid but do not have the stx gene; and atypical EPECs, which cause A/E lesions and have the eae gene but do not have the stx gene and the EAF plasmid (Nataro and Kaper, 1998). Thus, studies on virulence factors, infection forms and clinical symptoms have been essential to understand the pathogenesis of these bacteria.

Gouffaux et al. (2000) evaluated EPEC in humans, dogs and cats by isolating a heterogeneous group of genes using PCR and concluded that at least five genes of these EPEC isolated from animals were closely related to those of human EPECs. This demonstrated the zoonotic potential of dog's EPECs, an important cause of childhood diarrhea in developing countries (Nataro and Kaper, 1998).

The aims of this study were to investigate the therapeutic action of MOS in experimental infection caused by enteropathogenic bacteria in dogs; to evaluate the immune response and the presence of diarrhea; and to propose an in vivo EPEC infection model for young dogs.

\section{Materials and Methods}

\section{Bacterial strains}

Seven EPEC strains were used, four atypical $\left(\mathrm{eae}^{+}\right)$ and three typical $\left(e a e^{+}, b f p A^{+}\right)$strains (Beaudry et al., 1996; Nakazato, et al., 2004), as shown in Table 1. All samples were negative for the Shiga toxin gene (stx) (Blanco et al., 1997). Adherence characteristics of the strains used in the present study are shown in Table 1.

\section{Animals}

Twenty-five male and female Boxer dogs aged 60 days were used. The animals were selected from five litters of four sisters aged one and a half year. All animals were from the same breeder.

The parents were vaccinated (Vaccine Duramune ${ }^{\circledR}$ Max (Fort Dodge)) when they were pups and regularly dewormed (Vermifuge Endal Plus ${ }^{\circledR}(10 \mathrm{mg} / \mathrm{kg})$ ) at every four months. Pups were dewormed with Praziquantel and Pyrantel Pamoate when aged 20 days and vaccinated against distemper, infectious hepatitis, adenovirus type 2, parainfluenza, parvovirus and coronavirose when aged 45 days.
Table 1 - Characteristics of dog EPEC strains used in the experimental infection in vivo $(1,20)$.

\begin{tabular}{lcccc}
\hline \multirow{2}{*}{ Strains } & \multicolumn{3}{c}{ Presence of } & \multicolumn{2}{c}{ Adherence to HEp-2 cells } \\
\cline { 2 - 4 } & $e a e^{*}$ & $b f p A^{*}$ & EAF $^{\#}$ & \\
\hline 008 & + & - & - & LAL $^{\ddagger}$ \\
HE8 & + & - & - & - \\
SPA14 & + & - & - & LAL \\
SPA16 & + & - & - & NC \\
4225 & + & + & + & - \\
4083 & + & + & + & - \\
3549 & + & + & + & - \\
\hline
\end{tabular}

*eae: gene that codes for intimin.

bfpA: one of the genes responsible for codifying bundle-forming pilus.

"EAF: EAF plasmid detection.

${ }^{\sharp}$ LAL: localized adherence-like pattern.

NC: non-characteristic adherence pattern.

$+:$ positive.

-: negative.

Clinical examination and complete blood count were performed for the parents of experimental animals in order to evaluate their health status during mating. All pups were subjected to clinical evaluation at birth, at 20 days and 45 days after birth and before the beginning of the experimental period.

\section{Facilities}

After mating, females were kept in individual masonry kennels with covered area and solarium. From birth to weaning, at 30 days after birth, pups remained close to their mother in the same kennel. During the whole pregnancy and breastfeeding period, the mothers received animal food (AGR ${ }^{\circledR}$ Royal Canin) and clean and fresh water $a d$ libitum. During weaning, the pups of each litter were housed in kennels, where 3 pups of one same litter were kept in one masonry kennel which also had covered area and solarium; pups received the same diet provided to their mothers.

\section{Experimental infection}

The spread of $E$. coli strains was performed in BHI for $24 \mathrm{~h}$ at $37^{\circ} \mathrm{C}$ without agitation. This bacterial growth was centrifuged and resuspended in saline $(0.85 \% \mathrm{NaCl})$ until reaching Mcfarland scale $8\left(2.4 \times 10^{9}\right.$ bacteria/mL). The quantity of bacteria was verified by counting the colony forming units (cfu) in McConkey agar (Sigma). The animals were experimentally infected with $1 \mathrm{~mL}$ of resuspended bacteria by the oral route using gelatin capsules of intestinal release at a single dose. After $48 \mathrm{~h}$ of experimental infection, all animals presented liquid-to-pasty diarrhea without vomit. Feces were collected by using a sterile swab and inoculated into GN broth incubated at $37^{\circ} \mathrm{C}$ overnight for $24 \mathrm{~h}$, which was then sown on McConkey agar (Sigma) incubated at $37{ }^{\circ} \mathrm{C}$ for $24 \mathrm{~h}$; one sample per animal was 
used. One colony from each growth was selected, inoculated into Brain Heart 1nfusion (BHI - Oxoid) broth and incubated at $37^{\circ} \mathrm{C}$ overnight for genomic DNA extraction, as described by Gouveia et al. (2011).

\section{PCR}

For PCR of the eae gene, 50 ng DNA template were added to 2.5 U Taq DNA polymerase (Invitrogen), 50 pmol of each primer, $200 \mu \mathrm{M}$ deoxynucleoside triphosphate (Invitrogen), $1.5 \mathrm{mM} \mathrm{MgCl}_{2}$ (Invitrogen) and 1X PCR buffer (Invitrogen) at $25 \mu \mathrm{L}$ final volume (Nakazato et al., 2001).

After an initial denaturation at $94{ }^{\circ} \mathrm{C}$ for three minutes, samples was subjected to 35 thermal cycles at $94{ }^{\circ} \mathrm{C}$ (denaturation) for one minute, $56{ }^{\circ} \mathrm{C}$ (annealing) for one min and $72{ }^{\circ} \mathrm{C}$ for $40 \mathrm{~s}$. Reactions were performed in a thermocycler BioRad Laboratories, USA. A $5 \mu \mathrm{L}$ volume of each reaction was subjected to $0.8 \%$ agarose gel electrophoresis, stained with ethidium bromide or SYBR Gold (Invitrogen) and visualized in a transilluminator (Ultra Violet Products). Amplification of an $815 \mathrm{bp}$ fragment was expected (Nakazato et al., 2001).

For amplification of the eae gene, the following primers were used (Gannon et al., 1993):

EAE1: 5'ACGTTGCAGCATGGGTAACTC3' and EAE2: 5'GATCGGCAACAGTTTCACCTG3'

\section{Experimental design}

Five experimental groups were defined: Group A - no diarrhea induction and no MOS supply; Group B - diarrhea induction by the strain 4083 and no MOS supply; Group C diarrhea induction by the strain SPA14 and no MOS supply; Group D - diarrhea induction by the strain 4083 and MOS supply; Group E - diarrhea induction by the strain SPA14 and MOS supply

MOS was orally administered at $2 \mathrm{~g} / \mathrm{kg}$ live weight diluted in $2 \mathrm{~mL}$ water once a day during 20 days from $24 \mathrm{~h}$ after experimental infection. The inoculation day was considered the Day zero of the experiment.

Experimental design and statistical analyses followed the instructions of Kaps and Lamberson (2004). Experimental design was completely randomized with five replicates, and the effect of groups was analyzed at each moment. To evaluate the effect of moments for each experimental group, a randomized complete block design was adopted, considering the animal a blocked factor.

\section{Response variables}

All animals were clinically evaluated according to Jones (2003) at every six hours after experimental infection in the first five days. After this period, examinations were performed at every $24 \mathrm{~h}$.

\section{Clinical evaluation}

In all five moments of the experimental period (days $0,5,10,15$ and 20), the animals were also clinically evalu- ated through measurement of body temperature and assessment of dehydration degree (mild, moderate and intense), mucosal color (pale, pink and congested), vitality (apathetic, plays when stimulated and agitated), presence of blood in the feces (absent, little and much blood) and fecal consistency (normal, pasty and liquid).

\section{Laboratory evaluation}

Soon after clinical evaluation, a $5 \mathrm{~mL}$ blood sample was collected from each animal by jugular puncture. These samples were separated into two aliquots. The first aliquot was conserved in a sterile flask with anticoagulants (EDTA) at -2 to $8{ }^{\circ} \mathrm{C}$ for subsequent hemogram using an $\mathrm{ABC}$ Vet automated analyzer. The second aliquot was centrifuged and, after separation, the serum was kept at -2 to $8^{\circ} \mathrm{C}$ for subsequent determination of total IgA and IgG levels by ELISA (using the commercial kits IgA ELISA quantitation kit and Dog IgG ELISA quantitation set, Bethyl Laboratories). Of the samples obtained with the second aliquot, only those of days 0,10 and 20 after inoculation were used. After collection of each blood sample, the animals were individually weighed.

\section{Statistical analysis}

The results of hemogram, immunoglobulin dosages and fecal consistency of groups were compared at each moment by the Kruskal-Wallis test, while these responses at the different moments were compared for each group by the Friedman test, according to Kaps and Lamberson (2004). For all comparisons, significance level was set at 5\% $(\alpha=0.05)$.

\section{Ethics committee}

This study was duly approved by the Animal Experimentation Ethics Committee/Federal University of Mato Grosso do Sul (UFMS), protocol number: 116/2006. After the experiment, all animals had good health status.

\section{Results}

\section{PCR}

At the beginning of the experiment, seven EPEC strains were evaluated, 3549, 4083, 4025, 008, HE8, SPA14 and SPA16. All strains were tested by PCR and showed amplification of an 815 bp fragment, corresponding to the eae gene.

\section{Hemogram}

The medians of white blood cell concentrations at different days post infection (dpi) for animals of all experimental groups were calculated. There was no significant differences $(p>0.05)$ among groups at the several dpi and among dpi for the several groups. Before the experiment, hemogram and hemoparasite survey were performed and 
all animals were within the normal parameters for blood cells and had negative results for hemoparasite survey.

\section{Immunoglobulins $\lg G$ and $\lg A$}

The medians of IgA and IgG levels at different dpi for animals of all experimental groups were also calculated. There was no significant differences $(p>0.05)$ among groups at the several dpi and among dpi for the several groups.

\section{Clinical evaluation}

The body temperature of all animals remained within the normal limits, ranging from $38.5^{\circ} \mathrm{C}$ to $39^{\circ} \mathrm{C}$. No animal vomited or had dehydration symptoms, indicating absence of parenteral hydration over the experiment. Mucosal color remained normal and the animals were alert (not apathetic). Blood was not detected in the feces at any moment. Amplification of the eae gene ( $815 \mathrm{bp}$ ) by PCR led to identification of EPEC SPA14 and 4083 strains in the feces of all experimentally infected animals.

Results of fecal consistency for the different experimental groups and at different dpi are shown in Table 2.

All animals inoculated with EPECs had pasty diarrhea for 12-24 h, including the treated groups D and E. No control animal had symptomatology of intestinal infection, whereas animals of the remaining groups had intense diarrhea, presenting liquid feces at a certain moment over the experimental period. Bio-Mos ${ }^{\circledR}$-treated animals (Groups D and E) showed a significantly $(p<0.05)$ faster recovery relative to the animals that did not receive the prebiotic (Groups B and C). At fifteen days after treatments, all animals had already recovered.

\section{Discussion}

The action of MOS is to bind to type-1 mannose site in the bacterium, preventing the latter from binding to glycoproteins of intestinal cells. According to Ferket

Table 2 - Fecal consistency at five days of the experimental period for dogs subjected to different treatments*.

\begin{tabular}{lccccc}
\hline \multirow{2}{*}{ Groups } & \multicolumn{5}{c}{ Time points (days) } \\
\cline { 2 - 6 } & 0 & 5 & 10 & 15 & 20 \\
\hline A & normal & $\begin{array}{c}\text { normalpasty } \\
\text { diarrhea }\end{array}$ & normal & normal & normal \\
B & normal & pasty diarrhea & pasty diarrhea & normal & normal \\
C & normal & pasty diarrhea & pasty diarrhea & normal & normal \\
D & normal & pasty diarrhea & normal & normal & normal \\
E & normal & $\begin{array}{c}\text { normalpasty } \\
\text { diarrhea }\end{array}$ & normal & normal & normal \\
\hline
\end{tabular}

*A - No diarrhea induction and no MOS supply; B - Diarrhea induction by the strain 4083 and no MOS supply; C - Diarrhea induction by the strain SPA14 and no MOS supply; D - Diarrhea induction by the strain 4083 and MOS supply; E - Diarrhea induction by the strain SPA14 and MOS supply.
(2004), mannanoligosaccharides may stimulate the immune response against specific pathogens, preventing their colonization and promoting their presentation to the immune system as attenuated antigens. On account of such binding capacity with enteric pathogens (Spring et al., 2000), the process of activation by antigens of blood cells (neutrophils, lymphocytes and monocytes) would be impaired since the bacterium would leave the intestine without causing damage to the host. This may be the reason why cell immunity was not activated to a sufficient level. It must be emphasized that the type-I fimbria receptor (most common among $E$. coli) has D-mannose as receptor (the same as that of MOS); thus, the most probable mechanism of EPEC inhibition would be by competition of adhesion receptors. However, the hypothesis of immunoglobulin stimulation should not be ruled out.

There are few studies about the effect of prebiotics on the blood parameters of the several species, and those for the canine species are even scarcer. A situation similar to that of the present study was reported by Budiño et al. (2004) who carried out an experiment to test the addition of prebiotics for weaned piglets and did not find differences between treatments for haematological variables.

Laue and Tucker (2006) stated that pathogens and toxins associated with MOS form a great blend easily identified by the immune system. In our study, there was no change in serum IgA and IgG levels. Thus, future studies should quantify IgA from samples of the intestinal mucosa, which can be more easily stimulated by the blend formed by the association between MOS and pathogens/toxins.

The mucosa surfaces of the intestine develop active defense mechanisms mediated by cells and chemical factors, both related to innate (nonspecific) and acquired (specific) immunity. These systems show differences that, although not marked, are due to the different external factors to which they are subjected (Silva, 2006). For pups, these external factors, such as stress, cold and heat, are difficult to control, which influences the levels of immunoglobulins. This could be minimized if the number of animals were larger, as well as the number of replicates. In the present study, samples were from pups from sister mothers and the difficulty in carrying out experiments with a large number of specimens limited the number of samples per treatment.

Based on virulence markers associated with diarrhea in humans and animals, five diarrheagenic groups of $E$. coli were defined (Beutin, 1999), including the enteropathogenic group (EPECs), expressing colonization factors such as intimin (codified by the eae gene) and bundle-forming pili (BFP).

In the present study, typical (strain 4083) and atypical (strain SPA14) EPEC strains caused diarrhea in the animals at 24,48 and $72 \mathrm{~h}$ after induction, suggesting that both strains were pathogenic for the tested dogs. There was no difference between the results of typical and atypical sam- 
ples, which leads us to believe that the BFP fimbria was not essential for diarrhea manifestation; thus, BFP was not deeply investigated in the present study.

EPECs have virulence factors associated with several intestinal diseases in humans (Levine, 1984) and other animals (Pestana de Castro et al., 1984; Francis et al., 1991; Blanco et al., 1993). Since the dog is a domestic animal which lives closely with humans, the symptoms of natural infection caused by the studied strains indicate that animals could potentially contaminate humans and vice versa.

Nakazato et al. (2004) reported that the EPEC serotypes found in humans were also identified in other animals including dogs, demonstrating the zoonotic risk of EPEC from dogs. All E. coli samples isolated from the feces of inoculated animals had the eae gene, i.e. $100 \%$ of the isolated colony-forming units were EPECs, evidencing intense bacterial colonization of the intestinal epithelium, which indicates that dogs can represent an important source of EPEC infection for humans.

MOS had an effect on fecal consistency, and MOStreated animals recovered more rapidly from diarrhea than infected animals not treated with MOS. By means of competitive inhibition by mannose receptors, MOS decreases the effect of bacterial adherence by type-I fimbria in the intestinal epithelium of animals, an important process involved in EPEC pathogenicity. Since type-I fimbria is found in most Escherichia coli samples (Law, 1994), the presence of MOS may potentially have reduced the colonization or the perpetuation of colonization. Furthermore, the evaluation of fecal consistency (presence of diarrhea) showed that the process of bacterial adherence is extremely important in the emergence of diarrhea in EPEC-infected dogs.

In the present study, the EPEC infection model in dogs was established to determine the pathogenicity symptoms of these samples. Dogs infected with EPEC receiving MOS demonstrated faster remission of diarrhea.

\section{Acknowledments}

This study was supported by "Coordenação de Aperfeiçoamento de Pessoal de Nível Superior (CAPES)" and by "Embrapa Gado de Corte".

\section{References}

Beaudry M, Zhu C, Fairbrother M, Harel J (1996) Genotypic and Phenotypic Characterization of Escherichia coli isolates from dogs manifesting attaching and effacing lesions. J Clin Microbiol 34:144-148.

Beutin L (1999) Escherichia coli as a pathogen in dogs and cats. Vet Res 30:285-298.

Blanco M, Blanco JE, Ramos J (1993) Enterotoxigenic, verotoxigenic and necrotoxigenic Escherichia coli isolated from cattle in Spain. Am J Vet Res 54:1446-1451.

Blanco M, Blanco JE, Gonzalez EA, Mora A, Jansen W, Gomes TA, Zerbine LF, Yano T, Pestana de Castro AF, Blanco J
(1997) Genes coding for enterotoxins and verotoxins in porcine Escherichia coli strains belonging to different $\mathrm{O}: \mathrm{K}: \mathrm{H}$ serotypes: relationship with toxic phenotypes. J Clin Microbiol 35:2958-2963.

Budiño FEL, Thomaz MC, Kronka RN, Pizauro Jr, JM, Santana AE, Tucci FM, Fraga AL, Scandolera AJ, Huaynate RAR (2004) Influencia da adição de probiótico e/ou prebiótico em dietas de leitoes desmamados sobre as atividades das enzimas digestivas e parametros sanguineos. Acta Sci Anim Sci 26:529-536.

Collet S (2000) Nutrição, Imunidade e Produtividade. In: $10^{\mathrm{a}}$ Ronda Latino-Americana. Alltech - O Futuro da Alimentação. Alltech, Nicholasville, pp 20-30.

Cray WC, Moon HW (1995) Experimental infection of calves and adult cattle with Escherichia coli O157:h7. Appl Environ Microbiol 61:1586-1590.

Drasar BS, Hill MJ (1974) Human intestinal flora. Academic Press Ltd., London.

Ferket PR (2004) Raising drug-free poultry - What are the alternatives? Proc. $29^{\text {th }}$ Annual Poultry Service Industry Workshop. Banff, Alberta Canada, October 5-7, pp 95-104.

Francis CL, Jerse AE, Kaper JB, Falkow S (1991) Characterization of interactions of enteropathogenic Escherichia coli O127:H6 with mammalian cells in vitro. J Infect Dis 164:693-703.

Gannon VP, Rashed M, King RK, Thomas EJ (1993) Detection and characterization of the eae gene of shiga-like toxin producing Escherichia coli using polymerase chain reaction. J Clin Microbiol 31:1268-1274.

Gouffaux F, China B, Janssen L, Mainil J (2000) Genotypic characterization of enteropathogenic Escherichia coli (EPEC) isolated in Belgium from dogs and cats. Res Microbiol 151:865-871.

Gouveia EMF, Silva IS, Nakazato G, Araújo FR, Chang MR (2011) Experimental infection with enteropathogenic Escherichia coli (EPEC) identified by PCR using enteric-coated capsules in boxer pups. Acta Cir Bras 26:144-148.

Jones D, Anamnese e exame físico (2003) In: Birchard, S.J, Sherding, R. G (eds). Manual Saunders: Clínica de Pequenos Animais. 2 ed. Rocca, São Paulo, pp 5-6.

Kaper JB (1996) Defining EPEC. Vet Microbiol 27:130-133.

Kaps AM, Lamberson WR (2004) Biostatistics for Animal Science. CABI Publishing, London.

Laue D, Tucker LA (2006) Recent Advances in Pet Nutrition. Nottingham University Press, UK.

Law D (1994) Adhesion and its role in the virulence of enteropathogenic Escherichia coli. Clin Microbiol Rev 7:152-173.

Levine MM (1984) Escherichia coli infections. In: Germanier R. (ed). Bacterial Vaccines. Academic Press, London, pp $187-$ 235.

Nakazato G, Gyles C, Ziebell K, Keller R, Trabulsi LR, Gomes TAT, Irino K, Silveira WD, Pestana de Castro AF (2004) Attaching and effancing Escherichia coli isolated from dogs in Brazil: characteristics and serotypic relationship to human enteropathogenic E. coli (EPEC). Vet. Microbiol 101:169277.

Nakazato G, Osuguf L, de Ávila FA, Pestana de Castro AF (2001) Identificação pela reação em cadeia da polimerase (PCR) de amostras de Escherichia coli enteropatogênicas (EPEC) isoladas de cães com diarreia e normais no estado de São Paulo, Brasil. ARS Veterinária 17:218-223. 
Nataro JP, Kaper JB (1998) Diarrheiogenic Escherichia coli. Clin Microbiol Rev 11:142-201.

Pestana de Castro AF, Serafim MB, Brito JRF, Barcellos DSEN, Colli IAG (1984) Virulence factors present in cultures of Escherichia coli isolated from pigs in the region of Concordia, SC, Brasil. Pesq Vet Bras 4:109-114.

Silva VK (2006) Extrato de levedura (Saccharomyces cerevisiae) e prebiótico na dieta pre-inicial para frangos de corte criados em diferentes temperaturas. Jaboticabal, Brasil, 151 pp.
(M.Sc. Dissertation. Faculdade de Ciencias Agrárias e Veterinárias, UNESP).

Spring P, Wenk C, Dawson A, Newman KE (2000) The effects of dietary mannaoligosaccharides on cecal parameters and the concentrations of enteric bacteria in the ceca of salmonella-challenged broiler chicks. Poult Sci 79:205-211.

All the content of the journal, except where otherwise noted, is licensed under a Creative Commons License CC BY-NC. 